10.53116/pgaflr.2018.1.8

\title{
Rationalization of Legally Determined Expenditure as a Condition for Strengthening Financial Accountability
}

\author{
Eugeniusz Ruśkowski, ${ }^{*}$ Urszula Zawadzka-Pąk*
}

\begin{abstract}
* Eugeniusz Ruśkowski, Professor of Legal Sciences. Head of the Department of Public Finance and Financial Law, Faculty of Law, University of Bialystok, Poland. The author specializes in the theory of public finances and financial law, the public finance discipline, the public finances in the comparative perspective, the local government finances, the financial control, the budgetary law, the foreign exchange law. Author or Co-Author of forty-seven books and over 350 articles or chapters in books. President of the Association of the Centre for Information and Organization of Public Finance Research and Tax Law of the Countries of Central and Eastern Europe. (e-mail: eugen@list.pl)

** Urszula Zawadzka-Pąk, Doctor in Legal Sciences. Assistant Professor at the Department of Public Finances and Financial Law, Faculty of Law, University of Bialystok, Poland. The author specialises in the financial law and the public financial management, including the participatory budgeting, the public values, the fiscal rules and the performance management. Author or co-author of seven books and more than 75 papers or book chapters. Member of the Centre for Information and Organization of Public Finance Research and Tax Law of the Countries of Central and Eastern Europe, the International Political Science Association and the European Economic Association. More information can be found on her website: uzawadzka.org. (e-mail: u.zawadzka@uwb.edu.pl)
\end{abstract}

\begin{abstract}
The main purpose of this article is to analyse the relationship between financial accountability and legally determined expenditure. According to the adopted research hypothesis, increasing the financial accountability requires taking specific actions in the field of the legally determined expenditure. As the article is theoretical, it does not present the results of the empirical research; the formal-dogmatic method was used to interpret the content of legal acts and jurisprudence of the Constitutional Tribunal, as well as the non-obstructive method to analyse the foreign and Polish literature presenting the results of both theoretical and empirical research. In the article, having presented in the introduction the methodological issues, first, the principle of common good, the financial accountability, and the legally determined expenditure will be first explained. Next, the solutions for the rationalization of the legally determined expenditure will be proposed. We conclude that their implementation should increase the financial accountability to strengthen the constitutional principle of the common good.
\end{abstract}

Keywords: financial accountability; common good; legally determined expenditure; flexible expenditure; spending rules; multi-annual planning

\section{Introduction}

According to Art. 1 of the Constitution of the Republic of Poland of 2 April 1997, the Republic of Poland is the common good of all citizens. On the grounds of the Polish legislation, the common good is the constitutional value as well as the constitutional 
principle. On the grounds of the financial law, the public financial funds and an appropriate way of spending them should be the basis, though obviously not the only one, the instrument of the realization of the common good value (principle). This was confirmed by the Constitutional Tribunal recognizing a properly constructed (and balanced) budget as a necessary condition for the state to realize the goal of caring for the common good. ${ }^{1}$ However, the legally determined expenditure introduced without a sufficient analysis of social needs and the financial consequences of their implementation can be an important barrier to the implementation of the common good principle, as the resignation from the legally determined expenditure requires the positive intervention of the legislator. ${ }^{2}$

Therefore, the main purpose of this article is to analyse the relationship between financial accountability and legally determined expenditure. According to the adopted research hypothesis, increasing the financial accountability requires taking specific actions in the field of the legally determined expenditure. As the article is theoretical, it does not present the results of the empirical research; the formal-dogmatic method was used to interpret the content of legal acts and jurisprudence of the Constitutional Tribunal, as well as the nonobstructive method to analyse the foreign and Polish literature presenting the results of both theoretical and empirical research. In the article, having presented in the introduction the methodological issues, first, the principle of common good (section 1), the financial accountability (section 2) and the legally determined expenditure (section 3) will be first explained. Next, the solutions for the rationalization of the legally determined expenditure will be proposed (section 4). We conclude that their implementation should increase the financial accountability to strengthen the constitutional principle of a common good.

\section{Implementation of the Common Good Principle in a Representative Democracy}

An essential feature of the contemporary democratic systems is the choice of citizens' representatives to take the public decisions, including the financial ones, in their interest, and therefore in accordance with the common good. The implementation of the state's expenditure policy in the public interest, however, faces difficulties, as in today's democracies the activity of citizens generally is limited to the participation in the elections. ${ }^{3}$ Using the words of A. de Tocqueville, "each individual endures being bound because he sees that it is not a man or a class, but the citizens emerge for a moment from dependency in order to indicate their master, and return to it". 4

The election of the citizens' representatives in the elections process is accompanied by the principal-agent problem, which is the basis for explaining many phenomena in the sciences of public administration. This problem consists in that the rulers should not seek to pursue their own interests but they should take actions that serve only the public interest; however, in practice the citizens are unable to enforce their representatives and public administrators acting on their behalf not to pursue their own goals but the goals of society. ${ }^{5}$ Thus, the implementation of a policy that provides special privileges to groups that have narrow self-goals that run counter to the interests of particular voters and society as a whole does not serve the public interest. ${ }^{6}$ 
The basic cause of the problem of the principal-agent problem is the information asymmetry, as the information about the actions of public decision-makers is considered the common good. ${ }^{7}$ Lack of the reliable and transparent information on the implementation of the common good principle is a manifestation of the information asymmetry in the budgetary issues, analysed in this study.

An important role in strengthening transparency, and in consequence of the effectiveness and efficiency of public policy implementation, and thus the implementation of the common good principle can play the performance budgeting. However, in Poland, after several years of work on this instrument, launched in 2007, it has not become a subject of discussion in the parliament, nor even of more interest to citizens, hence its development boils down to a large extent to the formal implementation of labour-intensive obligations stemming from the Act of public finances ${ }^{8}$ and executive acts. However, even if the problems pointed out were solved, the performance budgeting alone would not solve the problem of the excessive legally determined expenditure, if not accompanied by additional instruments enabling rationalization of the non-elastic expenditure.

\section{Financial Accountability as an Instrument Supporting the Implementation of the Common Good Principle}

$\mathrm{N}$. Dias notes that nowadays all over the world we observe the disappointment with the representative democracy system. ${ }^{9}$ Similarly, A. Toffler sees the problem of modern democracy, where the mass of voters are so far removed from their elected representatives that the politicians are becoming less and less accountable to the citizens. ${ }^{10}$ Therefore, striving to propose the effective mechanisms for the implementation of the constitutional value of the common good, it was considered legitimate to consider the concept of accountability as the basis for further considerations, as the traditionally understood legal responsibility does not allow the effective enforcement of the common good principle.

While there are no definitional doubts regarding the legal responsibility, which means the incurrence or potentiality of certain entities to incur normatively determined negative consequences (sanctions) of certain events or state of affairs, ${ }^{11}$ there is a lack of the commonly accepted definition of the term "accountability". As A. Sroka notes, this term is most often used as a kind of "conceptual umbrella" under which various definitions are located. ${ }^{12}$ Accountability is based on various values and criteria, the most commonly used ones being procedural correctness, transparency, effectiveness, efficiency, usefulness, and sustainable development. ${ }^{13}$

Although the concepts of contemporary accountability researchers are not fully consistent, T. Schillemans, ${ }^{14}$ having made a synthetic analysis of 230 publications, determined that the minimum conceptual consensus in the area of accountability includes the following issues:

- Accountability is about providing answers towards others with a legitimate claim in some agents' work.

- Accountability is a relational concept: it focuses our attention on agents who perform tasks for others and thus may be held accountable by others. 
- Accountability is retrospective - ex-post - and focuses on the behaviour of some agent in general, ranging from performance and results to financial management, regularity or normative and professional standards.

- Accountability is not a singular moment or situation, but rather refers to a layered process..$^{15}$

In the definitions presented in the literature, the accountability is defined either as a social, administrative or political mechanism, institutional relation or arrangement in which a given person can be held accountable by another person or institution, or, less often as an advantage, the desired quality (value) of the state, governments or officials. ${ }^{16}$

Accountability is not a single moment or situation, but is a multi-stage process consisting of three analytically distinct phases:

- The information phase, when the agent renders an account on his conduct and performance to a significant other.

- The debating phase, when the principal assesses the information (transmitted orally or in writing) and both parties often engage in a debate on this account. The principal may ask for additional information and pass judgment on the behaviour of the agent. The agent will then answer questions and if necessary justify and defend his course of action.

- The sanctions or judgment phase, when the principal comes to a concluding judgment and decides whether and how to make use of available sanctions. ${ }^{17}$

Definitional difficulties, at least partially, result from the existence of the varieties of the accountability, of which only a part has been precisely explained. B. Wampler ${ }^{18}$ noted that the configuration of the three types of accountability, separated on the basis of the subjective criterion (the accounter) plays a particularly important role in strengthening financial accountability, i.e.:

- The vertical accountability is realized by the citizens (society) towards to public officials, the elected ones and expansively to administration subordinated to them, ${ }^{19}$ using its basic instrument (the election), during which voters can, at least in theory hold accountable for decisions realized in public interest. The main disadvantage of this approach limits the role of citizens to the only role of a voter, while the rulers make countless decisions affecting the well-being of each of them.

- The horizontal accountability, being the extension of the vertical accountability, is based on the distribution of authority among different departments or branches of government and the system of checks and balances. ${ }^{20}$

- The social accountability is realized by widely understood institutions of civil society. This kind of accountability, even if it is not legally institutionalized, can be particularly effective in strengthening the basic mechanisms of vertical and horizontal accountability. For example, vertical accountability may strengthen the disclosure of illegal practices of politicians, jeopardizing election results. In turn, horizontal accountability may lead to the destruction of the reputation of a corrupt public official, a lawsuit against public transport unit or a school that segregates in a racial manner. ${ }^{21}$ 
In turn, by applying the criterion of the subject (matter), to which accountability refers, among others, the educational accountability, the accountability in health care, or the ecological accountability can be distinguished. However, given the fact that almost every public policy requires public finances, the accountability for making decisions in the area of public expenditure and revenues (i.e. the financial accountability) seems crucial for the strengthening the common good principle.

In the literature as well as in government documents (in English) the terms "financial (fiscal) accountability" 22 as well as "budgetary accountability" 23 do exist, however, there are no definition or distinctive features. Analysing the context of the use of these terms, it can be stated that sometimes these terms are used interchangeably, ${ }^{24}$ however, more often the budgetary accountability means the accountability for the implementation of expenditure and revenues already planned in the budget, whereas the financial accountability is used in a broader context, as it is not limited to planned expenditure and revenue but covers public finances as a whole without budgeting them. Financial accountability refers to the potential use of public funds, it is not limited by the content of financial (budgetary) documents of an authorizing and planning nature, with a view to making the best use of available resources in the public interest. The analysis of the literature can also give the impression that in practice attempts are made to implement fiscal accountability, while financial accountability in the public sector still remains in the sphere of postulates and scientific considerations.

Thus it can be stated that on the ground of the financial law, the accountability, as opposed to legal responsibility, may not necessarily result from the legal norm. Moreover, accountability, unlike in the case of legal responsibility, does not have to be accompanied by the possibility of applying a legal sanction.

\section{Essence of Legally Determined Expenditure}

The legally determined expenditure is the part of public expenditure that the state is obliged to realise under the national or international law, contracts or court judgments. The etiology of this concept is therefore legal in nature, ${ }^{25}$ but it is distinguished primarily due to the systemic and organizational effects and economic consequences. The legally determined expenditure limit the freedom of decisions of state authorities regarding the optimal use of public funds, as they bind these authorities when determining the state budget expenditure. This can have negative effects on the improvement of expenditure efficiency, the size of developmental expenditure and the possibility of state intervention in emergency situations (e.g. the natural disasters, the economic crises). ${ }^{26}$

There are doubts related to the content of the legally determined expenditure of the state budget, and thus the question of what types of expenditure should be included in this category. Traditionally among the legally determined expenditure are classified: the subsidies for local government units, subsidies to the Social Insurance Fund and the Pension Fund, the expenditure on road infrastructure, the debt service of the Treasury, the national defence, the offices of the supreme state authorities, the control and protection of the law, the judiciary, the social pension, the family benefits (including financing the " $500+$ 
program" providing monthly payment of PLN 500 for the second and subsequent child) and benefits from the maintenance fund, the benefits from Child Support Fund, payments from Social Insurance Institution and Agricultural Social Insurance Fund, the social and health insurance contributions covered from the state budget, co-financing of projects with the participation of European funds, the pension benefits paid from the state budget, the subsidies for the State Fund for the Rehabilitation of Disabled People, own resources of the European Union. ${ }^{27}$

However, due to the fact that the concept and scope of the legally determined expenditure are not directly regulated by law, such selection will always be subjective. In the literature, other categories of public expenditure are sometimes considered as the legally determined expenditure, close to the legally determined expenditure or the quasilegally determined expenditure. ${ }^{28}$ This applies in particular to the expenditure of the state budget for multi-annual programs, for grants to local government units (especially commissioned tasks), etc. It seems necessary, at least for planning purposes, to develop an official methodology for determining (and possibly listing) the legally determined expenditure.

Most of the doctrinal studies regarding the expenditure of the legally determined expenditure concentrate on the establishment and the global criticism of the size of this expenditure. It is estimated that in Poland they cover about $75 \%$, whereas the flexible expenditure is about $25 \%$ of state budget expenditure. Very often, this global criticism, postulating a reduction in the level of the legally determined expenditure, ignores their diverse character regarding both the possibility of affecting their amount of state authorities, as well as the developmental character of some of them. We are against the method of the globalization of the legally determined expenditure, which in extreme cases may lead to the administrative determination of their border, advocating the need for individualized analysis of them and - as a result - the individual rationalization of the legally determined expenditure of the state budget.

The doctrine also postulates numerous and detailed changes in the scope of the legally determined expenditure. It is worth paying attention to two proposals, which may be of significant importance for further discussions of the rationalization of the legally determined expenditure. First, it is postulated to progressively withdraw from the so-called indexed expenditures in which changes relate to certain amounts or changes in other expenditure groups. ${ }^{29}$ This is not about the mere parametric construction of the regulations, which was treated as a specific achievement in legislation, but about the fact that often indicated parameters are not up-to-date because they come from many years ago, and deprive state authorities of the possibilities of flexible, current action. Second, in the opinion of some authors, the legally determined expenditure, the exceeding of a certain level (e.g. $75 \%$ of total budget expenditure): it should give the parliament the obligation to review sui generis "laws" giving rise to payment of benefits to third parties for the purpose of repealing them or the for future changes. ${ }^{30}$ It would also be an opportunity to renew the content of the social contract without revolutionary or fundamental system changes. ${ }^{31}$

Despite the critical attitude of the legal doctrine to the legally determined expenditure and their basic categories, it can be stated that in practice they grow from year to year in absolute numbers as well as in relation to total state budget expenditure. So there is a classic 
example of the contradiction between science and practice, which is quite common in the area of public finances and financial law (e.g. regarding target funds, de-budgeting, the simplicity of tax law, etc.). In 1998, the legally determined expenditure amounted to around $47 \%$ of state budget expenditure ${ }^{32}$ and were hence subject to constant, absolute and relative growth, with the exception of some decline in 2004-2006. In 2007 they reached the level of $73 \%$ of state budget expenditure ${ }^{33}$. In the report of the Council of Ministers on the implementation of the state budget for 2012, it is stated that the legally determined expenditure constitutes about $75 \%$ of the total state budget expenditure. ${ }^{34}$

The management of public finances in Poland in the last decade is subject to extremely opposite scientific assessments. Regardless of their reasons, two weaknesses in the fiscal policy of this period can be pointed out, also regarding the formation of the legally determined expenditure. The first one results from too little analysis of the risk of internal and external decisions regarding the public expenditure, the second is the failure to take or undertake with a long delay the necessary public finance reforms. The political struggle exerting a particular influence on the formation of the legally determined expenditure is intensified as part of election campaigns. Even if we assume that only a part of the election announcements will be implemented, their impact often increases the legally determined expenditure, making it difficult to achieve the balance of public finances. Fiscal policy directed at the rationalization of the legally determined expenditure should, therefore, concentrate on the first two reasons for shaping them, striving to eliminate (or limit) the other factors mentioned above. ${ }^{35}$

\section{Conditions of Rationalization of Legally Determined Expenditure Planning}

The critical attitude of the public finance science and financial law towards the amount and the structure of the fixed state budget expenditures has, to a small extent, affected the fiscal policy pursued in this area. Apart from some exceptions (e.g. J. Hausner's policy in the years 2004-2006), the public authorities limited their actions to single, uncoordinated activities, which cannot be called a detailed policy. In the recent period, even the notion the legally determined expenditure has been omitted in both the budget documents and the Multiannual State Financial Plan. The problem of the rationalization of the legally determined expenditure will not be solved spontaneously and automatically by the expenditure rules, multi-annual planning or performance budgeting - these are the instruments for an appropriate use in conducting detailed fiscal policy regarding the legally determined expenditure. Therefore, starting with the realization of spending review by the Polish Ministry of Finance should be positively assessed, unfortunately, they cover relatively narrow areas and to make it worse, not in a comprehensive way.

In this context, it will be particularly important:

- to develop a methodology to classify certain expenditure as the legally determined expenditure (broad or narrow approach),

- to present the problem and the amount of the legally determined expenditure structure for discussion to the government and parliament, using the detailed 
information about this expenditure in the justification of the budget bills and the descriptions of the Council of Ministers' reports on the implementation of the budget,

- to determine the treatment of the legally determined expenditure of the nonuniform nature, from the point of view of their flexibility and the impact on economic development (e.g. subsidies for local government units, the legally determined expenditure in the form of $2 \%$ of GDP on defence, which implies that at least $20 \%$ will be intended for property purposes),

- to develop the effective ways of encouraging the legislative bodies (Parliament, the Senate) to participate in the process of the rationalization of the legally determined expenditure, at the level of development of the assumptions and methodology of this process. The legally determined expenditure is an expression of the action of these bodies, not always acting on the request of the government. So imposing the principles and methodology of the rationalization of the legally determined expenditure by the executive bodies and the public managers may result in the indifference or the obstruction of the legislative bodies and repeat the negative experiences in this area with the introduction of performance budgeting in Poland, ${ }^{36}$

- to optimally use the existing achievements of bodies dealing with the introduction of performance budgeting in Poland, and partially also the rationalization of public expenditure, not to commit the error that new people are starting from the beginning to solve problems, already partly or completely resolved, ${ }^{37}$

- understanding that methods of limiting public spending should not be treated as the best (or even the only one) method of the rationalization of the public expenditure. Often, it may be in the interest of Poland to increase public expenditure or to reduce in a very slow peace. The point here is to launch mechanisms that on the one hand will replace one public expenditure with others, and on the other hand to cover new public expenditures with discretionary budget revenues. This conclusion fully applies to the rationalization of the legally determined expenditure. ${ }^{38}$

\section{Conclusions}

The conditions of rationalization of the legally determined expenditure presented above constitute an important, though obviously not the only one condition to increase the financial accountability in the field of public expenditure, both in terms of horizontal, vertical and social accountability. In the vertical and social dimension, the introduction of the transparent, reliable methodologically and the efficient methods for classifying the legally determined expenditure will allow meeting the needs of citizens (i.e. the principal in the electoral process) to a greater extent than before, limiting the electoral goals of politicians (i.e. agents). On the other hand, in the horizontal dimension of the accountability, determining the existing and desired scope of the legally determined expenditure will strengthen the rationality of planning, execution, and control of state 
budget expenditure. The above considerations allow confirming the research hypothesis adopted in the introduction, according to which the increase of financial accountability requires taking certain actions in the scope of the legally determined expenditure. However, it is conditioned by the existence of the reliable information and analysis of budget expenditure, and within them of the legally determined expenditure, carried out on the regular basis. It seems valuable to use British experience in this area. ${ }^{39}$

In conclusion, without denying the pertinence of the existence of certain categories of the legally determined expenditure, it should be borne in mind that they should serve the implementation of the common good principle, not accidentally expressed in the first article of the Constitution of the Republic of Poland. 


\section{References}

1 PL: Constitutional Tribunal, SK 36/07, III.4.

2 Urszula Kinga Zawadzka-Pąk, Shaping Financial Accountability Via Participatory Budgeting - Theoretical Framework For Axiological And Legal Analysis. Paper submitted for the XVII Center Conference entitled "Currency, Taxes and Other Institutes of Financial Law in the Year of the 100th Anniversary of the Founding of Czechoslovakia”, Prague 2018. https://doi.org/10.15290/acr.2018.11.11

3 In this regard the activity of civil societies acting in frame of the participatory (deliberative) democracy should be positively assessed - from the perspective of the political science, and in the frame of governance assessing from the perspective of the science of public management. Cf. Urszula Kinga Zawadzka-Pąk, op. cit.

4 Alexis De Tocqueville, Democracy in America, (Indianapolis, Liberty Fund, 2010).

5 Joseph Stiglitz, Ekonomia sektora publicznego [Economy of the public sector], 238-239 (Warsaw, PWN, 2013).

6 Arye Leo Hillman, Public Finance and Public Policy. Responsibilities and Limitations of Government, 73-74 (Cambridge, Cambridge University Press, 2004).

7 Ibidem. 76.

8 Public Finance Act of 27 August, as amended; compare: Eugeniusz Ruśkowski, Urszula Kinga ZawadzkaPąk, Activity-based budget in the light of theoretical principles and practical experiences of selected countries, 622-633, in Radim Bohác (ed.), Current issues of finance and financial law from the viewpoint of fiscal and monetary promotion of economic growth in the countries of Central and Eastern Europe after 2010 (Prague, Leges, 2010); Eugeniusz Ruśkowski, Urszula Kinga Zawadzka-Pąk, O możliwości wykorzystania w Polsce doświadczeń zagranicznych w zakresie budżetu zadaniowego [On the possibility of using foreign experience in Poland in the field of performance budgeting], 139-150, in Barbara Woźniak, Marta Postuła (eds.), Budżet zadaniowy metoda racjonalizacji wydatków [Performance budgeting as the method of the expenditure rationalization] (Warsaw, CeDeWu, 2012).

9 Nelson Dias, Twenty-five years of Participatory Budgets in the World: A New Social and Political Movement? 21-27, in Hope for Democracy - 25 Years of Participatory Budgeting (São Brás De Alportel, Nelson Dias, 2014).

10 Alvin Toffler, Szok przysztości [Future Shock], 472 (Poznań: Zysk i S-ka, 1998).

11 Wiesław Lang, Jerzy Wróblewski, Sylwester Zawadzki, Teoria państwa i prawa, 385. (Warsaw, PWN, 1986).

12 Anna Sroka, Rozliczalność w badaniach jakości demokracji (na przyktadzie Polski i Hiszpanii) [Accountability in research on the quality of democracy (on the example of Poland and Spain)], 17 (Warsaw, Elipsa, 2011).

13 Krzysztof Olejniczak, Organizacje uczace się. Model dla administracji publicznej [Learning organizations. Model for public administration], 54. (Warsaw, Scholar, 2011). https://doi.org/10.7366/9788373836327

14 Thomas Schillemans, The Public Accountability Review: A Meta-Analysis of Public Accountability Research in Six Academic Disciplines. Working Paper. 13-14. (Utrecht University School of Governance, 2013).

15 Ibidem.

16 Robert Goodin, Thomas Schillemans (eds.), The Oxford Handbook of Public Accountability, 7-10. (Oxford, Oxford University Press, 2014). https://doi.org/10.1093/oxfordhb/9780199641253.001.0001

17 Thomas Schillemans, The Public Accountability Review, op. cit., 13-14.

18 Brian Wampler, Participatory Budgeting in Brazil Contestation, Cooperation, and Accountability, 17 (Pennsylvania, Penn State University Press, 2007).

19 Guillermo O'Donnell, Horizontal Accountability in New Democracies, 3, Journal of Democracy (1998).

20 Adam Przeworski, Susan Stokes, Bernard Manin, Democracy, Accountability, and Representation, 50, (New York, Cambridge University Press, 1999). https://doi.org/10.1017/CBO9781139175104

21 Catalina Smulovitz, Enrique Peruzzotti, Societal and Horizontal Controls: Two Cases of a Fruitful Relationship, 311, in Scott Mainwaring, Christoper Welna (eds.), Democratic Accountability in Latin America. (New York, Oxford University Press, 2003). https://doi.org/10.1093/0199256373.003.0010

22 Anwar Shah (ed.), Participatory Budgeting, 2 (Washington, The World Bank, 2007). https://doi.org/10.1596/978-0-8213-6923-4 
23 Becky Carter, Evidence on budget accountability and participation (Birmingham, GSDRC, 2013).

24 Public Financial Accountability. Budget Documents, Quebec Gouvernement du Québec, 2017. Yves Herzberg Sintomer, Giovanni Carsten Allegretti, Participatory Budgeting Worldwide. 25 (Dialog Global, 2013). http://portugalparticipa.pt/upload_folder/table_data/c3164679-c343-4715-b198-576aee3d4ad1 /files/dialog-global.pdf (accessed 20 April 2018)

25 Teresa Dębowska-Romanowska, Charakter, Charakter prawny i klasyfikacja tzw. wydatków sztywnych a granice swobody politycznej władz państwa [Character, legal character and classification of the legally determined expenditure and the limits of political freedom of state authorities], in Jan Głuchowski, Alicja Pomorska, Jolanta Szołno-Koguc (eds.), Uwarunkowania i bariery w procesie naprawy finansów publicznych [Conditions and barriers in process of public finances repair], 279 (Lublin, KUL, 2007).

26 See: e.g. Piotr Russel, Wydatki budżetowe w Polsce [Public expenditure in Poland], Studia Biura Analiz Sejmowych [Studies of Parliamentary (Sejm's) Analysis Office] 3, 6 (2010); Agata Bury, Wydatki prawnie zdeterminowane w budżecie państwa, Zeszyty Naukowe Uniwersytetu Szczecińskiego [Legally determined expenditure in the state budget, Scientific Notes of University of Szczecin] 38, 33 (2011).

27 This list of the legally determined expenditure is presented by Budzyński, Tomasz, Opinia o ustawie budzetowej na rok 2013 [Opinion on the Budget Act for 2013], Opinie i Ekspertyzy [Opinions and Expertises], 198, 10 (2012).

28 Cf. Agata Bury, op. cit., 32; Alicja Kasperowicz-Stępień, Ksztattowanie się wydatków publicznych w Polsce w latach 2005-2009 [Public spending in Poland in 2005-2009], Zeszyty Naukowe Polskiego Towarzystwa Ekonomicznego [Scientific Papers of Polish Economic Society] 10, 88 (2011).

29 Cf. Alicja Kasperowicz-Stępień, op. cit. 91.

30 Therefore, the findings and recommendations included in two parts of the report of the Ministry of Finance on Spending Reviews related to the issue of the legally determined expenditure should be positively assessed. Cf. Przegląd wydatków publicznych: Mechanizmy waloryzacyjno-indeksacyjne oraz uwarunkowania prawne determinujące poziom wydatków sztywnych, w szczególności w obszarze wydatków socjalnych. Część I i II [Valuation-indexation mechanisms and legal conditions determining the level of legally determined expenditure, in particular in the area of social spending. Part I and II] (Warsaw, Ministerstwo Finansów [Ministry of Finance], 2017).

31 Teresa Dębowska-Romanowska, op. cit., 292.

32 Alicja Kasperowicz-Stępień, op. cit. 87.

33 Cf.: Jerzy Żyżyński, Budżet i polityka podatkowa. Wybrane zagadnienia [Budget and tax policy. Selected Issues], 97-98 (Warszawa, PWN, 2009).

34 Sprawozdanie z wykonania budżetu państwa za okres od 1 stycznia do 31 grudnia 2012 r. Omówienie [Report on the implementation of the state budget for the period from 1 January to 31 December 2012. Description], 54 (Warsaw, Rada Ministrów [Council of Ministers], 2013).

35 For more details on the essence of the legally determined expenditure cf.: Eugeniusz Ruśkowski, Wydatki sztywne budżetu państwa [Legally determined expenditure of state budget], Zeszyty Prawnicze Biura Analiz Sejmowych [Legal Notes of Parliamentary (Sejm's) Analysis Office], 10-17 (2015).

36 Eugeniusz Ruśkowski, Urszula Kinga Zawadzka-Pąk (ed.), Prawne problem konstrukcji i funkcjonowania budzetu zadaniowego we Francji. Wnioski dla Polski [Legal problem of the construction and functioning of the performance budgeting in France. Applications for Poland], 103 and the following (Białystok: Temida 2, 2010).

37 Marta Postuła, Instrumenty zarzadzania finansami publicznymi [Public finance management instruments], 150 and the following (Warszawa: Wydawnictwo Naukowe Wydziału Zarządzania Uniwersytetu Warszawskiego [Scientific Publisher of the Faculty of Management at the University of Warsaw], 2015).

38 Eugeniusz Ruśkowski, Wydatki sztywne [Legally determined expenditure], op. cit., 20-21. 
39 Urszula Kinga Zawadzka-Pąk, Instrumenty nowego zarządzania finansami publicznymi w Wielkiej Brytanii [Instruments of the New Public Financial Management in the United Kingom], 151-174, in Eugeniusz Ruśkowski (ed.), Instrumenty nowego zarządzania finansami publicznymi w wybranych krajach Unii Europejskiej [Instruments of New Public Finance management in selected European Union countries], (Białystok: Temida 2). 